\title{
INSTITUTE OF OWNERSHIP IN THE POST-COMMUNIST REPUBLIC OF ALBANIA
}

\author{
Besmir ALUSHI \\ Erjola ALIAJ**
}

\begin{abstract}
Ownership as a genuine institute of civil rights in the Republic of Albania began to be considered complete only after the change of political systems. Until this period, ownership was a fragmented and incomplete institute due to the fact of the existence of public property, which was one of the principles of the ideology of the monist system. With the change of the corpus of domestic legislation and the signing of international agreements ratified in civil law, the concept of private property will undergo a fundamental change. Building a civil code totally different from the existing one would bring about a different treatment of private property. In the new code, private ownership would be of paramount importance both from a doctrinal and practical point of view. The implementation of the legislation would be a challenge in itself which, in addition to the positive part, will also face issues that are still part of the law practices. The focus would be on restitution and compensation of property to former owners but at the same time the private property institute would address in itself the new ways of acquiring probationary property, property protection and everything else related to this institute of which is considered a fundamental right by the Constitution of the Republic of Albania and the European Convention on Human Rights.

Keywords: Institute of property; civil law; civil code; private property.
\end{abstract}

DOI: 53373 / REDS.2021.53.4.045

\section{Historical overview of property rights after 1990}

The Republic of Albania in the period from 1945-1990 continued to be part of the countries with a communist political system. The relatively long period would reflect negative consequences which would affect the life, health, safety, property and any other rights of individuals. Changing the political system, moreover, would present difficulties in changing legislation and drafting new legislation. The Constitution of the Republic of Albania would undergo profound changes due to the very nature that the old constitution would present. The changes would affect all its parts, starting with the basic principles, fundamental rights and freedoms of the individual, political freedoms and rights, functioning, organization and activity of the three powers, regulation of public finances, definition of constitutional institutions and everything else related to national security. These radical changes would initially encounter difficulties in the perception of society due to the longevity of the previous system which was limited compared to the new regulations which

* Lecturer Ph D and researcher in Mediterranean University of Albania.

${ }^{* *}$ Lecturer Ph D and researcher in Mediterranean University of Albania. 
were applicable in Western countries for more than a century. Criminal legislation would be drafted without encountering difficulties as the field of its coverage, procedure, subjects, criminal offenses and basic principles would be based on European legislation and the approach would be realized within a short time but always with periodic changes according to the needs of society at certain moments sometimes affected by emergencies created. The difficulty in changing and adapting the legislation would be ascertained in the civil legislation due to the fact that the old legislation did not provide important institutes of civil legislation, such as ownership, rights and obligations, commercial legislation for private entities and special laws governing relations. Lack of legislation would not be the only difficulty in drafting new legislation, but the relationship between civil law entities in the field of ownership with public institutions would turn into chaos. Restitution and compensation of property for former owners who after the change of the political system who demanded the return of rights related to private property would result in a difficult challenge crossing the limits of the impossible. It should be noted that the Republic of Albania during the years of rule of the communist political system, against the owners of movable and immovable property took measures to confiscate private property and transfer private property in favor of the state. The first pluralist government formed after 1945 took immediate action in creating new legislation, which should be adapted to the legislation of democratic countries due to the fact that the Republic of Albania would aspire to become part of international bodies in certain fields. The signing of ratified international agreements would be another challenge for the Republic of Albania in drafting domestic legislation in accordance with treaties, conventions and any other international agreement. The amendment of the constitution would be seen as the first initiative of the Republic of Albania to move to the new democratic system. Law No. 7449 dated 29.4.1991 on the Main Constitutional Provisions would serve as a starting point for the new legislation already in a democratic spirit. The right to property as a fundamental human right would be sanctioned in the provisions of this law of a constitutional nature. According to the principles of law, the economy will be developed based on the variety of properties, the free initiative of all entities and the controlling role of the state. Subjects of property rights according to the provisions of the law on constitutional provisions will be the state, legal and natural persons as well as all types of property enjoy equal protection by law. Public property which is related to state property objects in any case will be determined by a special law due to the determination of the public legal entity that owns them and consequently there will be a need to provide for them in the special law. With regard to foreign legal entities, special laws will again provide for ways of gaining ownership for this category of entities. 


\section{The constitutional and international importance of property rights as a fundamental human right}

Referring to the Constitution of the Republic of Albania, property is considered as the basis of the economic system in the Republic of Albania. The Constitution defines the legal protection of private property by considering it as a fundamental right of the individual. The meaning of the guarantee that the Constitution has given to the right to private property, is the meaning of a fundamental right that is closely related to individual freedom, thus preserving its private function. The Constitution of the Republic of Albania enables a general regulation of the right to private property by defining the ways of gaining ownership, issues related to restrictions and property rights which find their full meaning in the provisions of the Civil Code of the Republic of Albania. The right to private property is guaranteed. Property is acquired by donation, inheritance, purchase and any other classic way provided in the Civil Code.

The law may provide for expropriations or restrictions on the exercise of property rights only in the public interest. Expropriations or those restrictions on property rights that equate to expropriation are allowed only in return for a fair remuneration. Disputes regarding the amount of compensation can be appealed in court. The content of the above provision gives a general understanding of the right to acquire property. The classic ways of acquiring property rights are provided in the provisions of the Civil Code which will be addressed in the following chapters of this paper. Restriction of the right to property as a fundamental right is presented in two forms through expropriations and restrictions related to the exercise of this right. Expropriation is considered the most severe form of restriction of property rights, although the Constitution and the European Convention on Human Rights in any case provide for expropriation by setting the condition of fair compensation. Expropriation not only has to adhere to the condition of a fair reward but the concept of expropriation is closely related to the public interest. In any case, the expropriation will be carried out only for public interests, which means that the individual is violated in the right to private property, but this violation comes as a result of the good and interest of the general public. Following its provisions, the Constitution has sanctioned the protection of property rights, emphasizing that its violation cannot be committed without a proper legal process.

In this sense, private property falls into the category of fundamental rights which the Constitution considers indivisible, inalienable and inviolable and underlie the entire legal order. The European Convention on Human Rights with its additional protocols guarantees supranational protection of this right. The right to private property is enshrined in the Additional Protocols to the European Convention on Human Rights. Article 5 of the Convention stipulates that every natural or legal person has the right to the peaceful enjoyment of his possessions. No one shall be deprived of his possessions except in the public interest and subject to the conditions 
provided for by law and by the general principles of international law. As can be seen, the Constitution and the European Convention on Human Rights follow the same spirit in the protection of property rights. The convention, as provided for in the Constitution, guarantees the legal protection of property, but also the restrictions that can be placed on property, which in any case will be implemented for reasons of public interest and against fair compensation.

\section{Ownership in interpretation of the provisions of Law No. 7850, dated 29.7.1994, Civil Code of the Republic of Albania}

\section{Meaning and content of the right of property}

Principled provisions of the law on constitutional provisions would serve as the basis for supporting subsequent civil laws. Law No. 7850, dated 29.7.1994 "Civil Code of the Republic of Albania" will be considered as the basic pillar of the new civil legislation in the Republic of Albania. Ownership would be treated as a separate institute in this codification of laws, giving 'extraordinary importance to itself the nature it enjoys. Private property is considered a sacred right in the constitutions of European countries, giving it the same importance as other "sacred" rights such as the right to life and the right to liberty and security of person. The Civil Code of the Republic of Albania has defined ownership as "the right to enjoy and dispose of things, within the limits set by law". From the content of this provision arise some elements which require interpretation from a legal point of view. The ownership relationship will be directly related to the items, which will further constitute the object of this relationship. Items to be the object of the legal relationship of ownership can be of different types, such as movable and immovable, main and accessory, consumable and non-consumable, etc.

Items according to the definitions and meaning given by the Civil Code will be considered as material goods that may constitute the object of ownership or other real right. So the right of ownership is a set of norms that will regulate the social relations that have as their object the ownership over things. By the notion of property we mean objects as the object of the legal relationship of ownership. Property and ownership are two notions that are related one to the object of the legal property relationship and the other to the content of this relationship. Ownership as a legal relationship has some distinctive features which can be classified into: Real, property, absolute character, of the pursuit of the thing, stable and continuous. Ownership is a real legal relationship, its subjective right enters into real rights. The owner exercises his right without the help of third parties. Based on this fact, the right of ownership enters into the real rights and this makes it different from the rights of obligations. In its essence the right of ownership has a property character because its object as we have mentioned above are the things. The owner of the items in any case has the right to demand the item from any other person who holds it illegally even if the other person holds it in good faith. The stable and continuous 
character is related to the fact of not ending in time, so this right does not end with the expiration of a certain deadline but it continues even after the expiration of the deadlines.

\section{The relationship of property rights with other civil law institutes}

Property law has its own characteristics which make it different from other civil law institutes. Other institutes of civil law provided in the Civil Code of the Republic of Albania are: Subjects of civil law (natural and legal persons), legal actions, inheritance (legal and testamentary) rights and obligations and representation. Property rights cannot be seen in isolation from other civil law institutes. Civil law subjects must in any case enjoy ownership of certain items in order to have a legal relationship whose object will be related to the right of ownership. Ownership will also be the subject of mortis causa legal relations. The object of inheritance will be the transfer of rights from the testator to his heirs according to the ways and procedures provided by the provisions of this code. The object of transfer of rights may be property rights which are subject to the rules and provisions established in the institute of ownership. In relation to the institute of rights and obligations, the object of contractual legal actions may again be ownership.

Representation as an institute of civil law will mean the performance of legal actions within the scope of the law, power of attorney or court in the name and on behalf of a natural or legal person. Representation in its object may provide for the performance of legal actions on certain items that constitute the property of certain subjects of civil law. As can be seen, the institutes of civil law are closely related to the institute of property law and in any legal action performed, its object can originate from the institute of property law.

\section{Property rights tags}

In the real and temporary real rights recognized by the civil legal system we have ownership, servitude, usufruct, use, possession, residence and servitude. The object of ownership will be the objects and any other real right that will be related to the objects. Ownership between real rights is the right which includes more rights that subjects can exercise over the thing. Belonging to things has to do with the material side of property rights which, according to doctrine, are called "corpus" but ownership is fully defined through the elements that make up what is called the spiritual side "animus". Possession, joy, and mood determine the animus or tags given to the owner. Together with the ownership over the items, they constitute the content of the property right. The above-mentioned rights are the powers of the owner with which he realizes the right of ownership. The definition of property rights is important to define the right of ownership as a fundamental real right but also in cases where other real rights are exercised by third parties. 
The right to enjoy the thing, the right of joy

The right to enjoy the thing will find its source in Roman law by referring to the right to use and receive fruit or 'Jus utendi fruendi' and the right to use and misuse the thing or 'Jus utendi et abutendi'. The tag of joy is related to the right that the owner has to use the item. The use of the item will be performed by the owner in order to meet the needs and extract income from the use of the item. This tag gives the owner a choice in the use of the item, in the destination he gives the item, possible transformations that the item may undergo and the right to destroy it if deemed reasonable. The main element related to the tag of joy has to do with the fact of using the item according to its economic purpose. Use for this purpose will enable the owner to gain material benefits. The tag of joy will be accompanied by the tag of possession of the thing.

\section{Right to dispose, disposition fee}

Jus disponendi or disposition tag is part of the tags that fall under the right of ownership. Mood tag is the ability of the owner to decide on the fate of the item by alienating it by changing the economic destination for which it was created, or by destroying it. Based on these rights that the possessor is the holder, this right (power) can be considered as an essential right of the owner. By disposing of the thing, the owner can change his legal status at any time, always by performing legal actions. In case the owner appears as a subject in the legal relations of the obligation, he again has the right to change the legal status of the thing as well as its destruction when the need arises. As a result of the above, the right of disposal is the right of the owner to transfer the thing to third parties with legal actions inter vivos or mortis causa. Disposal is the right of the owner to sell it or not, to donate it or not, to inherit it or not to third parties. The right of disposition also includes the rights of the owner to give real guarantees, or to guarantee the obligations to third parties. The tag of mood often times in legal practice, happens to be confused with the tag of joy but the difference is made at the moment of arrival of the consequence. The right to destroy, annihilate or misuse an item is a common feature of both the enjoyment and the disposition. These rights come as a result of the economic predestination of the thing. The disposal of unnecessary items is a consequence of the disposition of disposition, while the expenditure of fuels is a consequence of the entitlement of joy. The owner can exercise the rights of possession, joy and disposition himself, but he can also exercise the possessions of possession and joy through third parties.

\section{Power of possession and possession as a separate right}

\section{Meaning of possession and types}

Possession is an element of the content of the property right and enters into the rights of the owner. Possession is defined as the effective rule of a person over an object and other real rights over it. Possession can be exercised directly or by a person holding the thing. Referring to civil law, possession is considered as an element of the content of the property right but also as a separate right, independent 
of the property right. The double treatment of the possession right comes as a result of the exercise of this right by the possessing owner but also by the non-owner possessor. In case this right is exercised by the owner, it is considered as a right of ownership, but when this right is exercised by the non-owner possessor, the possession is treated as a real right in itself. Possession by a non-owner possessor may be lawful or unlawful. Possession is lawful if the possessor has acquired possession from the owner on the basis of legal action, law or administrative act. If the possessor has not acquired possession in any of the ways provided for above the possession will be considered illegal. Illegal possession can be in good faith or in bad faith. The meaning of possession derives from the content of the legal norm which defines it as the effective rule of a person over a certain thing. Possession in the legal sense does not require the person to keep the thing as his own as owner but it is enough for the relationship of the thing to exist with the possessor.

The relationship must definitely bring economic benefits or satisfy the legitimate interests of the possessor. Possession according to the provisions of the Civil Code derives several types of it. Possession is legal when the possessor has possession from the owner, based on a legal action, based on law or an administrative act. In all other cases possession is illegal. In interpreting the above provision, we understand that lawful possession will be considered in cases where the right has been transferred to the possessor by the owner of the thing. Possession even though it is treated as a right by itself again it remains inseparable from the right of ownership. Possession as a right in itself will be achieved if the possession is exercised by a person other than the owner, and the possession has passed from the owner. In order to understand in which cases we are dealing with legal possession and illegal possession, not only must the thing have passed from the owner to the possessor and he must be a different person from the owner, but it must necessarily be the owner to pass the thing through legal actions, based on the special law that will regulate this relationship, or by an administrative act. The establishment of these ways will be related to the creation, change or termination of the respective legal relations. All legal actions, law and administrative act must result as lawful actions to be in conditions of lawful possession. Legal possession is acquired voluntarily, when the legal actions performed by the parties are realized with their will and compulsorily when it is acquired as a result of performing legal actions, is according to legal requirements. All the above cases are related to legal possession, while illegal possession is when the possessor has not acquired possession in any of the ways of gaining legal possession, by legal action, by law or by administrative act. Illegal possession also exists in cases when it has been acquired by legal action or administrative act but the legal action or administrative act must be invalid as in these cases the legal cause or legal title did not exist or has fallen at a later time. Illegal possession is in itself divided into good faith and bad faith. The provisions of the Civil Code have given meaning to possession in good faith and in bad faith. Illegal possession can be in good faith or in bad faith. Possession is in good faith when the possessor did not know or was not obliged to know that his possession is 
illegal. Trust is presumed and it suffices to have been at the time of gaining possession. The illegal possessor is in good faith in cases when even though he has shown his care for this relationship, he is convinced that the possession of the thing was acquired by the owner based on a legal action, a legal administrative act. So illegal possession in good faith must meet all the elements of legal possession and be based on a title and in good faith of the possessor. The title, although it seems legal, it would not be so, so it can be obscure, fictitious in order to be considered invalid. The possessor will be in bad faith in all cases in which it does not appear to meet the elements of good faith. The possessor in bad faith has acquired possession of the thing without legal reason, against the will of the owner or lawful possessor of the thing.

\section{Ways to gain possession}

The ways of gaining possession are provided in the provisions of the Civil Code. Possession is acquired through legal actions, inheritance and occupation. He who has acquired possession in good faith, may combine in his possession, also the time of possession in good faith of the person from whom he acquired the thing. Possession is acquired by legal action, inheritance and occupation. In contrast to the property right for which a variety of ways of acquiring it is known, possession will be acquired by legal action, which in all cases must be found valid. Acquisition of possession by inheritance refers to the institute of legal or testamentary inheritance. In any case, the inheritance must result in a valid legal action and performed in accordance with the provisions of the Civil Code for the institute of inheritance.

\section{Protection of possession}

The Civil Code has provided special provisions which come in the protection of possession. There are several forms of protection of possession which consist in the protection of the latter, the cessation of the violation of possession and the restoration of possession.

\section{Then protection}

By that protection we mean the right of the possessor to object immediately by using an appropriate protection against any action intended to infringe or deprive him of possession. In case the object of possession has been taken by force or in secret, the possessor in any case has the right to take it immediately or in pursuit. We will not be in the conditions of protection of possession if the then protection will be accompanied by acts of violence and do not agree with the circumstances of the event. In this type of protection, possession of an element to be valued and considered is the element of time. From the violation of possession in the then protection should not have passed a relatively long time, so the defense should be realized on the spot, efforts to protect possession should be current without passing a long time. The right to protect possession is recognized not only to the possessor but also to the holder of the thing, against any person other than the one from whom 
these rights come. From the above provision we understand that the holder of the thing, although not the possessor, has the same rights of self-defense as the possessor.

\section{Termination of encroachment on possession}

The protection of possession, in addition to the protection after that, is also realized through the lawsuit of termination of the violation of possession. In order for the protection of possession to exist through the cessation of the infringement of possession, there must be certain conditions, the existence of which will be fundamental to the realization of such protection. The person, who is encroached upon in the possession of an item, can request within six months, the cessation of the encroachment on the possession and not its repetition in the future. When the possession was acquired by force or secretly, the lawsuit may be filed within six months from the day the violence or secrecy ceased. Termination of the encroachment on possession may not be requested by the person who acquired the possession by force or secretly. Violation of possession will mean any interference, whether with actions or omissions by third parties which will prevent the possessor from exercising possession, but in no case will the item be removed from possession. So the elements that must be met to be protected with this type of lawsuit are, the time limit of 6 months, as if the possession has not been removed by the possessor. In filing a lawsuit, the possessor has the right in his research to express the cessation of the violation of possession and not to repeat the violation in the future.

\section{Restoration to possession}

The possessor, who has been illegally deprived of possession, has the right to request within six months, his reinstatement in possession. This right does not belong to the possessor who took possession by force or secretly. When the undress is secret, the time limit for seeking restitution of possession begins on the day the undress is discovered. Restoration may also be sought against one who has acquired possession through a title but who was aware of the deprivation that occurred. When adjudicating a lawsuit for termination of infringement or reinstatement in possession, the defendant may not claim to be the owner himself or to have a stronger right than that of the possessor. Deprivation of possession is the most serious form of encroachment on possession. Deprivation of possession means illegal interference by which the possessor has been deprived of the thing from his possession. For filing a possession lawsuit there must be some conditions such as: On the one hand the plaintiff must have been the possessor of the thing at the time of undressing and on the other hand the defendant to perform the intervention which forms the unlawful deprivation of the plaintiff's possession of the item. In his claims, the plaintiff, in addition to the request for reinstatement in possession, can also claim compensation for the damage that may have come to the possessor from the deprivation that was done to him from the possession of the thing. 


\section{CONCLUSION}

The Institute of Property Law and the Institute of Immovable Property Registration are pillars of the civil legal field as well as the focus of our study in this paper. Problems related to domestic legislation but also to the overlap of decisions of various institutions have generated confusion in the field of ownership, due to the fact that there is a lack of a basic data that holds accurate and complete information about property rights. The property right in the Republic of Albania is the institute of civil law which has undergone fundamental changes for reasons which have been identified in this paper. Frequent legal changes have hampered the implementation of legislation leading to delays in the service of citizens, and in many cases not providing final solutions to the problems raised. The formation of the first government in Albania after the Second World War according to the model of the Eastern bloc would continue with the confiscation and nationalization of private property. The legal changes would then consist of the disappearance of private property and its transfer in favor of the state. These actions would restrict the owners in the right of ownership and in all cases would not benefit from fair compensation. With the change of the political system, the legislation on property would be subject to a long procedure which consisted in the drafting and periodic change of the legislation, the unification of the judicial practice, the creation of institutions which would have in their object of activity the issues that relate to ownership. It should be noted that the initiatives taken by the state authority have been to be appreciated as issues related to private property have been among the most difficult tasks of the executive power in the Republic of Albania for the post-communist period. It should be noted that the construction of legislation in recent years in accordance with the directives of international bodies such as the European Union has given positive results and many problems have been resolved within a reasonable time. But in many cases it has not acted efficiently in both the construction of legislation and its implementation. In certain parts, the legislation is not built in accordance with the requirements of the entities that benefit from the right of private property. Law 7501 On land was the first initiative for the allocation of agricultural land in favor of certain individuals who had to meet the legal criteria to be beneficiaries of this law. The law was opposed by interest groups such as former owners whose previous political power restricted them from ownership. Their claims were related to the fact that the first action was to solve the problem for this category and then the government dealt with the allocation of land to former agricultural families. The law also displayed content issues which were reflected in the following years causing chaos in resolving other issues related to property rights. The establishment of the Property Restitution and Compensation Agency and the drafting of special legislation would then be seen as the final solution for the former owners whose properties were confiscated. Legislation on restitution and compensation of property in content again showed reservations but with the beginning of its application the 
former owners found a partial solution to their issue. The implementation of this law would face institutional bureaucracy, delays which were caused not as a result of the process but as a result of mismanagement by officials and officials of all levels of public administration. The law on restitution and compensation of property would undergo constant changes, but again failed to provide a final solution to the problem related to the category of former owners. The cases, as they did not find administrative solutions, were subject to court proceedings, which again show problems both in the proper implementation of the law by the courts and in the delays of several years until their completion. Certain cases have been tried by the European Court of Human Rights in which the former owners acquired the right of ownership after having followed the national court path and were not given a fair solution. In these cases it should be noted that the costs of expenditures are borne by the Albanian state by reducing revenues in the state budget. The ways of gaining ownership from the point of view of drafting the law has been in accordance with the legislation of developed European countries. The legislation which has provided the ways of gaining ownership has been complete but in certain periods being affected and certain situations, the legislation has been supplemented with the issuance of special laws which would be seen as new ways of gaining ownership. In this regard, the acquisition of ownership would face institutional difficulties, due to delays in the actions and inactions of institutions in completing legal proceedings to legitimize the new owners. The implementation of the law in this regard will be considered difficult in the delays that would appear, but again it should be emphasized that its application came to the aid of certain entities. Immovable property registration would again present difficulties for entities that sought real estate registration in order to complete the process of acquiring, recognizing and registering real estate. Institutions established for the registration of real estate as the final segment of the process would create bureaucratic difficulties which come as a result of inactions of the administration for the registration of real estate. The created situation would face the dissatisfaction of the former owners who would again spend unnecessary time, energy and financial means for the registration of their legal assets.

\section{References:}

- Nathanaili, A., "Pronësia", Ribotim i vitit 1974.

- Besnik Maho (2013) Fitimi i pronësisë mbi pasuritë e paluajtshme " UETPRESS

- Biçoku, N.,"E Drejta e Trashëgimisë e Republikës së Shqipërisë”, Ribotim, Tiranë 1997.

- Kaloshi, F., "Regjistrimi i pasurive të paluajtshme", Botim i vitit 2013.

- Musta, B.,\& Qato, M., "Si të regjistrojmë pasurinë e paluajtshme", Botimet Geer, Tiranë, 2005.

- Xhaj, V. \& Çevi, K., Regjimi juridik i Tokës në Shqipëri”, Botim i Ministrisë së Bujqësisë, Tiranë 1956.

- Meçani, D., "Pronësia mbi tokën", Triptik, Botim i Parë, vitit 2008.

- Latifi, J.,"E drejta Civile”, Pjesa e Përgjithshme, Tiranë 2007.

- Shehu, A., "Pronësia", Botim i vitit 1998.

- Kondili, V.“E drejta Civile”, Pjesa e Përgjithshme, Botim i vitit 2007. 
- Kondili, V.,“E drejta Civile II”, Pjesa e posaçme, Pronësia të drejtat të përkohshme dhe trashëgimia, Shtëpia botuese Geer, Botim i vitit 2008.

- Semini, Marjana., "Leksione mbi të drejtën e pronësisë dhe regjistrimi i saj sipas legjislacionit në fuqi", Shkolla e Magjistraturës, 2009.

- Semini, Marjana., "E drejta civile", Pjesa e Përgjithshme

- Nuni, A.\& Hasneziri. L., "E drejta Civile II "Pronësia”, Tiranë 2010.

- Nuni, A.\& Hasneziri. L., "E drejta Civile III Trashëgimia”, Tiranë 2010.

- Nuni, A.\& Hasneziri. L., "Leksione të së drejtës së pronësisë”, Tiranë 2007.

- Komentar i Kodit Civil, "Obligimet dhe kontratat përgjithësisht”, Shtëpia Botuese "Luarasi", Tiranë 1998.

- Galgano, Francesko. E drejta private 1. Pronësia, Tiranë, 2003

- Shehu, Avni." Pronësia", Shtëpia Botuese e Librit Universitar,1998

- Nuni, A. "E Drejta e Pronësisë, Tiranë.

- Maho, Besnik., "Regjistrimi i Pasurive te Paluajtshme një kusht i domosdoshëm për formalizmin e titujve të pronësisë, si dhe për të rritur transparencën në këtë fushë", Artikull i botuar në Revistën Shkencore "Jus \& Justicia" e Fakultetit Juridik, UET Press, Tiranë,

- Gërxhi, J. "Një vështrim i përgjithshëm mbi praktikën e regjistrimit të pasurive të paluajtshme si domosdoshmëri për garantimin e të drejtave të individëve mbi pronën", Artikull i botuar në Revistën Shkencore "Jus \& Justicia" e Fakultetit Juridik, UET Press, Tiranë, Nr.3/2009. 